\title{
China and African Development: Partnership not Mentoring
}

\author{
Jing Gu and Anthony Carty*
}

Abstract This article states the conclusions of major field research into the impact of Chinese public and private economic activity on governance in Africa. China has gone into parts of Africa and sectors of African activity where Western actors have been reluctant to venture, yet receives criticism for not reaching standards of governance which the West itself is not able to apply. The Chinese go into Africa on a basis of equality and partnership but are unclear how to impose standards of conduct which are not integral to a consensual relationship or how to guide the development of standards which they do not have at home. China is itself engaging in a continuing process of economic reform and increasing privatisation. Nonetheless, it has developed a doctrine of effective governance in Africa which stresses responsibility and accountability, provision of basic services and social stability, a central Chinese objective at home and abroad.

\section{中国与非洲发展: 合作伙伴而非师徒关系}

谷靖, 安东尼・卡蒂

中国在非洲发展中发挥的作用不断增大, 关于中国官方和民营部门经济活动对非洲 治理产生的影响, 本文在实践研究的基础上, 提出了几个论点。首先, 中国在非洲 开展经济活动的许多地区和领域是西方不愿进入的。但是, 中国却因为未能达到所 谓的治理标准而受到批评, 而这些标准西方本身因为并非身临其境根本就无法去应 用。第二, 平等和伙伴合作是中国在非洲开展经济活动的基础, 因此在中国看来, 将特定行为标准强加于非洲不仅与中非关系基于共识的本质不合, 而且中国也没有 权力这样做。第三, 这一点在中国国内的反思性文献中表现得尤为清楚一一中国人 不知道如何能期望他们在非洲施用或者指导非洲建立中国国内都没有的治理标准。 第四, 中国本身正在经历一场仍在持续的经济改革, 这意味着中国经济的私有化程 度将越来越高。目前, 中国经济活动中不受中央政权管控的私营部分已经越来越 大。最后, 尽管如此, 中国在非洲还是建立起以对当地人民负责为重点的实际有效 治理原则。对于中国政府来说, 无论在国内还是在海外, 治理最首要的目标都是提 供基本服务和维护社会稳定。 


\section{Introduction}

We have seen the increasing engagements of rising powers in Africa. The role of China in international development has risen to prominence in recent years. The objective of this study is to identify and evaluate the implications of China's emerging role for governance and development in states experiencing 'fragile' socioeconomic and political conditions in subSaharan Africa. The article's primary focus is on understanding better and explaining the drivers behind China's growing presence in this region, and makes reference to Rwanda and the Democratic Republic of the Congo (DRG).

\section{China's domestic dynamics and its external activities}

China's domestic and external development experiences are interrelated. China's approach to governance is closely linked to its own development experience, illustrated by slogans such as 'Development first, governance second', 'Unleash people's potential', and 'If the water is too clear, no fish can be found'. China's foreign aid is largely based on the requests of recipients. This means three things. The first is that China rarely goes to the recipient on its own initiative to design aid projects, besides some landmark ones. After China receives these requests from the recipients, there is certainly an internal evaluation process about whether to provide aid and how to carry it out. If the projects are related to concessional loans, the EximBank will take the responsibility to make the evaluation. It also seems likely that China's budget constraint on aid is very strict, and is therefore often unable to meet the request of the recipient. According to the authors' interviews, the officials of the Ministry of Commerce (MOFCOM) often have complaints on several issues. On the one hand, the size of China's aid is quite small. So some officials feel it is very strange that the West wants to cooperate with China because China certainly provides less aid than many Western countries. On the other hand, they are also short of personnel to manage the existing aid projects. China's rapid economic growth has resulted in the domestic salary and living standards improving at tremendous speed while the standard of compensation from the government for people who go abroad to work on aid projects has not been improved accordingly for a long time. Thus, it has become more and more difficult for MOFCOM to mobilise human resources. ${ }^{1}$
China's foreign aid, moreover, cannot be completely understood through a 'rational' process. This does not mean there is not rationality behind China's aid but that as some MOFCOM officials put it, compared with the West, China's foreign aid certainly lacks a longterm strategy. One MOFCOM official argued that China's aid is not as complicated as the West cares to believe. From this official's understanding, they simply do what they can for recipients according to the budget. It has also been heard that the EximBank also complains about the limited government funds available to them. If the government can raise the scale of aid, more concessional loans may be provided for proper projects. Thus, it seems that MOFCOM and the EximBank do not positively design China's aid according to some specific strategy or purpose but only do what they can do with the current budget constraint. ${ }^{2}$ Some have claimed that the financing is achieved for policy-related purposes where funding is applied for from the Ministry of Finance. In fact, this process is in actuality quite similar to China's governmental budget as a whole. The government's spending does not depend on a rational budget and the tax collected according to it, but it simply spends how much it can collect.

It is very difficult to argue, in governance terms, that China's foreign aid is based on any clear strategy. Overall, China provides foreign aid mainly based on the so-called 'friendship' between China and its recipient countries in the Chinese discourse and the aid is political rather than developmental in nature. Although under the impact of the Western development discourse China has begun to use the term 'international development cooperation' more and more often, most people still think about aid as primarily political. But it is the Ministry of Foreign Affairs rather than MOFCOM that deals with China's strategic plan and diplomatic policies. For this reason we often hear complaints from the Ministry of Foreign Affairs regarding MOFCOM's aid programmes. ${ }^{3}$ Recently, the Ministry of Foreign Affairs established its new department of international economy. Currently this domestic institutional dilemma remains unsolved and it shall be interesting to see how it is resolved.

From the recipients' perspective, China's foreign aid is generally welcomed for two reasons. The first is that China's aid is based on the principle of 
non-interference and without political conditions. This essentially gives the recipients more bargaining power when they negotiate with China on aid projects. Secondly, the differences between China's foreign aid and Western aid provide alternatives for recipient countries and give them more choice; this is especially the case in Africa.

The DRC and China, for example, have an agreement signed in 2008, the Convention relating to the development of mining and infrastructure projects in the DRC. This agreement formed the basis for a joint venture, named Sicomines, between one Congolese company on behalf of the DRC state and two Chinese firms designed to implement the agreement and get the projects into place. Here, the DRG gains valuable infrastructure through Chinese funding and project expertise provided by the agreement and the Chinese parties are reimbursed through the joint venture's returns and production outputs.

Generally speaking, within the whole implementation mechanism of China's foreign aid, the decision-making process is still a black box. We still lack detailed information on topics like the negotiation process between the Chinese government and recipients, the interaction between MOFCOM, the Ministry of Finance and the Ministry of Foreign Affairs, and the operational procedure between MOFCOM and other organs of implementation. This kind of information cannot be obtained through interviews because Chinese government officials are quite sensitive about these topics.

\section{Conceptual framework}

The article works through two key concepts: 'governance' and 'fragile states':

\section{(a) Governance}

Within Western academic and, to a significant extent, policy circles, the key pillars of governance are reasonably well established, even if the actual content is often contested. In summary, there are four central elements within what may be loosely termed 'a' Western perspective: authority, reciprocity, trust and accountability. Authority refers to 'legitimate power', rather than the exercise of arbitrary power undermining the public sphere, and alienation or rejection by the citizenry. Reciprocity is 'a form of social interaction that generates new forms of consensus about basic rules of politics' and is based on 'future expectations of returns'. Trust refers to trust between families and kinship groups, but also to 'impersonal trust between different groupings and towards public authorities'. Finally, accountability refers to 'the responsiveness of public authorities towards citizens and the extent to which citizens can hold public authorities to account' (Kjær 2004: 164). As categories, each of these constitutive elements is held to have a universal applicability and, in principle, are central to the Western Powers' approach to the promotion of governance in sub-Saharan African states and to the 'reconstruction' of states regarded as fragile.

\section{(b) Fragile states}

A widely used definition of fragile states is that: 'States are fragile when state structures lack political will and/or capacity to provide the basic functions needed for poverty reduction, development and to safeguard the security and human rights of their populations' (OECD 2007). However, it is important to engage with Putzel's argument that there needs to be greater definitional clarity regarding the term 'fragile states':

At the core of the problematic definition of state fragility used by the international development community is a misguided belief that the institutional practices of advanced democracies and developed economies need to be transferred all at once to the poorest countries. There is also a resistance to identifying that some of the practices which states use to achieve peace and stability state resilience - violate precepts of market liberalism and notions of good governance (2010: 4).

China's engagement with Africa has often been reduced to an issue of exacerbating existing governance issues, which is seen by some as an extension of China's own lack of concern for human rights and accountability at home (Alden 2007). Hence, we need to understand the relational dynamics of Chinese and African political brokerage. Sketchily, we know that these relations are essentially between elites (Carmody and Taylor 2010) and that they create unaccountable enclaves within states such as Angola (Power, Mohan and Tan-Mullins 2012; Corkin 2011). While these elite relations engender projects that deliver infrastructure 
(Foster, Butterfield, Chuan and Pushak 2008) and produce resource rents, it is unclear how far these are developmental.

\section{Chinese understanding and approach to 'governance' and 'fragile states'}

To distil China's rapidly evolving approach to governance down to a few basic facets is, naturally, challenging. However, based on extensive author interviews and secondary research in China and Africa, there are five key aspects that come to the fore:

China's approach to governance is very much linked to its own development experience. China views concepts such as transparency, participation and the rule of law as ethnocentric Western norms. Rather than talking of 'good governance', China focuses on 'effective governance', building real capacities, and pragmatic engagement with partners on the ground that will lead to long-term partnerships that are mutually beneficial. China's view is that overcoming state fragility requires state resilience, without which effective governance cannot be reached. For the immediate future, China's conception of governance will remain different from that of the West.

- Despite Chinese government policy to encourage overseas investment by Chinese firms and their perception that this offers a 'win-win'strategy for Africa, links between Chinese government policy and business sector firms are in practice relatively weak. The Chinese officials and academics interviewed concur in the view that these relationships are currently fluid. Consequently, there are spaces and opportunities for China's public and private sectors to build constructive relationships that contribute to both Chinese and African development goals.

- China does not seek to shape African states in its own image or interfere in politics, but it is realising that it cannot simply pretend that the problems of its local partners do not exist, or are exclusively the concerns of those countries. As its investments in fragile states grows, China has become increasingly interested in the ways in which the West has tried to handle African problems in the past and is opening up to the idea of dialogue with Western and non-Western donors and international agencies. This bodes well for efforts to bring China into initiatives such as the Extractive Industry Transparency Initiative and the Equator Principles.
China is in Africa for business, it is not in Africa to improve African governance. That is a Western way of thinking. China views African development as dependent on Africans, not outside partners. While China's engagement with African countries provides for many of the conditions they need to develop (investment, infrastructure, opening new markets, better prices for African products, and so forth), China's developmental impact will depend on how African leaders operate the relationship. Fragile states must create a conducive policy environment for investment, promote local investment in joint ventures, and train African entrepreneurs so that skills and technology can be transferred. Thus, getting basic governance right is necessary for African countries to make the most of their relationships with China.

- Within the field of development cooperation, the growth in weight and influence of China is clear. However, at present, China is at the 'crossroads' in trying to work out how to use its rapidly growing power and is in the process of defining its core overseas national interests. Hence, how to communicate with the outside world and to be understood better is very important for China, and it is also very important to the traditional OECD donors and African countries.

The first point to make in explaining 'governance' in the Chinese context is that it is a concept that is gaining increasing attention and serious intellectual and policy deliberation. Effective 'governance' is, in Chinese usage, synonymous with a strong state and efficient public administration that gains legitimacy and public support through the quality of its authority, reciprocity, trust and accountability grounded in an appeal to a national future. All these elements transfer readily to Chinese perceptions of African governance. The basic premise of governance is the primacy of economic development (Chen and Li 2011: 56). Therefore, these authors emphasise that economic development is of overriding importance for governance (ibid.). $\mathrm{Li}$ and $\mathrm{Xu}$ argue that the most significant factor in fragile states is that of a failure of effective output ( $\mathrm{Li}$ and $\mathrm{Xu}$ 2010: 51). The potential for disaster and chaos, they suggest, spilling over to neighbouring countries would not only cause a serious humanitarian crisis, but also pose a grave challenge to international order because of the multinational criminals and terrorist groups 
seeking to exploit such fragile conditions. Their answer to this problem is to support the processes of improving state resilience through a strong state administration (Li and Xu 2010: 52; Zhou 2011).

China's own emphasis is on state resilience - on state-building. China's prerequisite is societal stability and orderliness inculcated via a strong state supported by the Communist Party. This is taken from China's domestic experience of transition of a velocity and breadth that is unprecedented in the modern era. Inevitably, this attracts criticism. One does not mean this is a fully self-aware or deliberately conceived approach to governance by China to be held up as a model for other developing countries. Indeed, this is explicitly denied and eschewed among Chinese development specialists and foreign policy staff. Nonetheless, the importance of a strong Chinese state as a 'developmental state' cannot be overlooked in its potential appeal, especially for fragile states.

Putzel's argument is that a definition of 'state fragility' that is useful for policy intervention needs to highlight what distinguishes fragile states from the rest of low-income developing countries. This means recognition of the importance of the achievements of states in establishing a significant degree of 'resilience': 'The counterpoint to state fragility is not development, but state resilience, [authors' emphasis added] which may be a stepping stone to more dynamic development, or a plateau marked by economic stagnation, beyond which it is difficult to pass' and that there is a 'huge distance that must be traversed from both conditions of fragility and stagnant resilience to a situation where the state is presiding over accelerated growth and poverty reduction' (2010: 2). Nevertheless, state fragility involves the failure of the rule of law; impotent state institutions; illegitimate or non-inclusive government; a weak economy; fragile civil society and a vulnerable environment (France Cooperation 2007: 3).

Attaining these basic functional attributes in the case of China has, clearly, been a long, bitter and often bloody experience and a sense of national vulnerability remains embedded in the political culture, discourse and political practice domestically and internationally, 'China's rise' notwithstanding. As a consequence, the Chinese government is reluctant to proselytise publicly to fragile states. While Western governments, including the UK, suspended their official development assistance (ODA) to Rwanda in July 2012 because of allegations of it giving covert support to rebels in Eastern DRC, China has not followed suit.

\section{China and Rwanda}

China's engagement in Rwanda is driven mainly by its need for natural resources, political support and access to consumer markets. Although Rwanda has nowhere near the amount of natural resources as other fragile states such as the DRC, the political support it offers for the 'One China' policy as well as to China as a responsible stakeholder in multilateral fora is valuable. For Rwanda, China is an attractive source of investment and aid because it provides an alternative to traditional donors, which increases the countries' negotiating options in order to maximise assistance. China's system of state capitalism also allows it to make longerterm commitments and take on building large infrastructure projects at lower costs.

Rwanda has had much more success in managing Chinese involvement in line with its national interests. Since the genocide, Rwanda has strengthened its government, implemented wide-ranging reforms to attract investment, and elaborated 'Vision 2020', its national development strategy. In 2011 Rwanda was the second fastest growing economy in sub-Saharan Africa. In the last few years, Rwanda's trade with China has grown faster than with any of its other partners, doubling from 2009 to 2012 to reach a value of $\$$ US160 million.

Rwanda has proactively facilitated investment and trade with China by including Rwandan business people in its official delegations to China and establishing a Rwanda Development Board office in Shenzhen, which promotes opportunities and advises the Rwandan government on policies that will encourage Chinese investment. Contrary to popular views, most of China's investments are not in the natural resources sector, but in transformative sectors like telecommunications and manufacturing. Rwanda has particularly targeted information and communications technology (ICT) as a sector where China can help it become a regional leader. It has engaged 
Chinese enterprises such as ZTE and Huawei to provide equipment and transfer expertise in order to upgrade technology, enhance e-governance programmes, and establish a new ICT Park in Kigali. Through its diplomatic engagement with China, Rwanda has also been approved as an official tourist destination for Chinese citizens as well as tariff-free access to China for 95 per cent of its exports.

When Rwanda was accused of supporting the M23 rebel group in the DRC, Western donors withdrew their aid. However, just as the cuts were beginning to hurt the economy, China gave Rwanda US\$35 million in interest-free loans and grants, despite China's strong support for Kabila's government in the DRC. Thus, we can see that China has not developed a comprehensive framework for dealing with this inter-state crisis politically. Its traditional inclination is to remain outside conflicts for which it does not have any deep, direct knowledge and experience. However, as China is involved in both countries and even contributes to the peacekeeping mission in the DRC, it will need to develop a framework for analysis beyond its philosophy of resilient state development.

Rwanda has welcomed China's aid, trade and investment with open arms. In the aftermath of the 1994 Rwandan genocide, strengthening ties with China helped Rwanda rebuild and grow economically. The Chinese Ambassador to Rwanda, Shu Zhan, said that 'Rwanda's ability to turn itself around after the atrocities of 1994 is a tremendous achievement in itself which merits being supported both emotionally and financially' (Touchot 2012). Rwanda's relationship with China has been crucial more recently, as Western countries suspended aid due to reports that Rwanda was backing the M23 rebel group in the DRC. Western countries suspended aid due to reports that Rwanda was backing the M23 rebel group in the DRC. As noted above, China's US $\$ 35$ million funding deal came just as the cuts began to hurt the economy, consisting of US\$19 million as an interest-free loan and US\$16 million in grants (Kagire 2012).

Ambassador Zhan said that China would not dictate how Rwanda should use the money, and that 'China intends to back Rwanda over the next two years it will hold the UN (Non-Permanent Security Council) seat' (ibid.). Thus, since 1971, Rwanda and China have built a positive and increasingly strong relationship predicated on their respective political and economic interests.

\section{Overview of Chinese projects}

Since 1972, China has supported well over 30 projects in Rwanda through the framework of Economic and Technical Cooperation. Most projects involve financing and constructing infrastructure, but there have also been projects in agriculture, education, health and trade.

In terms of infrastructure, the China Road and Bridge Corporation (CRBC) has rehabilitated and built many roads in Rwanda, including the Kigali Rusumo Highway (162km, completed in 1977), the Parliament House Kininia Road $(3.5 \mathrm{~km})$, the Kinyinyia Textile Mill Road $(2.6 \mathrm{~km})$, the Rusizi Rubavu Highway $(66 \mathrm{~km}$ at US\$116 million) and the Kigali Genocide Memorial Centre Road (Ministry of Commerce 2006). The CRBC is the largest Chinese stateowned construction company in Africa, and has been working in Rwanda for over 30 years, with an office in the country (Touchot 2012). In 2009 China provided an interest-free loan to Rwanda of US\$37.8 million, 35 per cent of which was used to rehabilitate the Kigali road network.

China has also funded construction (1987) and refurbishment (2005) of the Amahoro National Stadium, the Prime Holdings conference centre (2004), and the Ministry of Foreign Affairs building (at US\$8.6 million) (Ministry of Commerce 2006). Gurrently, the Kigali Convention Centre is being constructed by the Beijing Construction Engineering Group (BCEG) at the cost of US $\$ 226$ million (MININFRA 2013). In April 2013 the China State Construction Engineering Corporation (CSCEG) was awarded the construction contract for the Bugesera International Airport to the tune of US\$650 million (Ssuuna 2013).

China has offered technical assistance to Rwanda in agriculture by turning swamps into irrigated paddy fields in Rwamagana (1982) and Umutara (2000) (Ministry of Commerce 2006). China has also supported demonstration and training initiatives for Village Mechanization Service Centres at the Kabuye-Kigali central workshop.

In the health sector, China constructed and later expanded the Kibungo Hospital, built the Kibungo Medical Training School in 2005, the 
Masaka District Hospital, and has consistently supported the work of rotating Chinese medical teams in Rwandan hospitals (Ministry of Commerce 2006). China has also donated medical equipment and malaria medicines to Rwanda, as well as offering support for the maintenance of medical equipment.

In terms of industry, China built a cement factory in Western Province that is now run by CIMERWA (Rwanda's only domestic cement producer), which currently has the capacity to produce 100,000 tonnes of cement per year. China also constructed a sugar factory at Kabuye Kigali, the army brick factory, and the Rwamagana rice-husking factory (Ministry of Commerce 2006).

As for education, China is obliged to provide Rwandan students with nine university scholarships annually, but in practice it has offered many more than this minimum. In 2012 over 40 Rwandan students received scholarships to study in China, and 160 Rwandans from various fields were sent to attend workshops in China to improve their skills. China built an agro-veterinary secondary school in Western Province, a vocational school in Northern Province, and also established a Confucius Institute in Kigali to teach Chinese language and culture. In 2011 the Institute had about 300 students, and was starting to teach Chinese in some Rwandan high schools. In the future, it plans to offer courses in universities and primary schools as well (Magistad 2011).

\section{Chinese investment}

Chinese foreign direct investment (FDI) in Rwanda is small-scale, making up less than 1 per cent of China's total FDI in Africa. However, from the Rwandan perspective, it is significant, forming an average of 5.6 per cent of FDI between 2003 and 2007 (ACET 2009: 24). Chinese FDI flows were at US $\$ 1.4$ million in 2005 , and rose to US\$12.7 million in 2010. In terms of stock, investments rose from US\$3.3 million in 2004 to US\$41.6 million in 2010. Driving investment are the positive views of Rwanda as a country that is determined to protect investors and become a regional financial hub.

Contrary to popular views, most of China's investments are not in the natural resources sector, but in transformative sectors like telecommunications and manufacturing. Between 2000 and 2009, the Rwanda Investment and Export Promotion Agency registered nine Chinese investment projects cumulatively worth about US $\$ 46$ million (ibid.). This represents around 4.3 per cent of all registered projects during that period. These investments were made by ALink Technologies and Fadar Ltd (ICT), Star Communications and Huawei Technologies (telecommunications), LIU Xinen S.A.R.L., Rwanda Toothpaste Company and Zong Wang International Leather (manufacturing), the Great Lakes Refinery (mineral refining) and the China Rwanda Product Wholesale and Re-export Promotion Centre (services). These investments created a considerable number of jobs, with the re-export centre alone employing 1,000 Rwandans (ACET 2009: 25).

In 2012 two of the top ten investments registered by the Rwanda Development Board (RDB) involved China. The largest investment, at US\$162 million, was a joint venture with China to build a resort outside Kigali called Eagle on the Lake (Hitimana 2013). The fourth largest was a US $\$ 92$ million investment by the Chinese construction company Gentury Park Hotels and Residences Ltd to build a Sheraton Hotel in Kigali (d'Amour Mbonyinshuti 2013).

The three major challenges Chinese investors face in Rwanda are communication across Chinese, English, French and Kinyarwanda, the limited pool of skilled labour in Rwanda, and sometimes the difficulty of finding cost-effective access to raw materials. Still, as John Gara, CEO of the RDB says, 'the figures for Chinese FDI are not yet as high as we would want them to be, but certainly we are beginning to see interest' (Namata 2011). From the Chinese perspective, Li Jinzao, the Vice Minister of Commerce stated that:

China and Rwanda have good relations. Chinese companies have been playing an important role in the economic development of Rwanda and have undertaken the construction of roads, electricity facilities and water supply as well as investment in digital TV broadcasting in Rwanda. So, our future is promising (MINAFFET 2013).

\section{Trade between Rwanda and China}

Over the past few years, Rwanda's trade with China has grown faster than with any of its other 
trading partners, doubling from 2006 to 2007 and reaching US\$100.8 million in 2008. Between 2004 and 2008, Rwanda's imports from China grew by 700 per cent (Kariuki, Byusa and Ogunleye 2009)! By 2010 Rwanda imported more goods from China than anywhere else in the world, at a value of US $\$ 195.80$ million. This represents a share of 15.6 per cent of Rwanda's overall imports. In the same year, Rwanda exported US $\$ 18.8$ million worth of goods to Hong Kong and US\$17.3 million to China, shares of 8.1 per cent and 7.4 per cent respectively (National Institute of Statistics 2012).

Although both imports and exports have grown, Rwanda imports much more from China than it exports to China, leading to a significant trade deficit in China's favour. Rwanda's imports from China are primarily electronics, building materials, shoes, clothes and machines for manufacturing goods like bricks and tea bags. China mostly imports things like rawhides, and minerals from Rwanda. For example, Rwanda exports 10 per cent of its tin ore (valued at US $\$ 3.8$ billion), 42 per cent of its nobium and tantalum (US $\$ 8.2$ billion) and 57 per cent of its tungsten ores (US\$10.2 billion) to China (Malunda and Musana 2012). In 2013 the Chinese government extended duty-free treatment to 95 per cent of Rwandan exports. If Rwandan businesses can figure out how to take maximal advantage of this and start exporting more value-added goods, it promises to boost the competitiveness of goods from Rwanda as well as the country's export earnings.

There are a few challenges for trade between Rwanda and China. The first is the language barrier. This creates problems of communication and can also make it difficult to establish trust between trading partners. ${ }^{4}$ The Confucius Institute in Kigali is working on this, by teaching Rwandans Chinese, as well as providing opportunities for Chinese business people to familiarise themselves with Rwandan languages and culture. China has also launched a campaign to communicate its business practices and measures that are in place to facilitate trade. The Economic and Commercial Counsellor's Office of the Chinese Embassy in Rwanda has been involved in the process of building positive relationships.

Secondly, there is a perception in Rwanda that many goods from China are unsafe or cheap because they are of bad quality (Kariuki et al.
2009). In response to this, the Rwanda Bureau of Standards has been established, but it is still in its infancy. While China does not take responsibility for the choices of Rwandans to buy cheap goods, it does promote Rwandans learning more about the Chinese goods that are available by sponsoring their travel to trade fairs in China. About 100 Rwandans take advantage of this opportunity each year.

Third, Rwanda's transport infrastructure poses a challenge as the country is landlocked and goods must be brought over long distances on an inefficient road network to ports in neighbouring countries. This makes both imports and exports for Rwanda more expensive. ${ }^{5}$ While geography cannot be helped, China has been significantly involved in upgrading roads, and Rwanda has plans to build a railroad network that will make transport easier, cheaper and faster.

A fourth challenge is that it can be difficult for Rwandan business people to gain entry to China's market. This is partly due to language barriers, but also because the length of commitments favoured by the Chinese are quite short, six months being a typical contract term (Kariuki et al. 2009). This requires Rwandan business people with limited exposure to international trade to negotiate contracts carefully and deliver quickly. China supports Rwandan business people by inviting them to China for official visits, providing them with entry and facilities at Chinese trade fairs, and disseminating information to Chinese buyers about products available from Rwanda.

Despite these challenges, trade between China and Rwanda promises to grow, diversify and provide benefits to both parties. Even though the balance of trade favours China, Rwandans benefit from access to low-cost consumer goods and Rwandan businesses gain from access to lowcost production machinery. Meanwhile, China gains access to buyers and minerals, and current efforts to improve Rwandan agriculture could also lead to food imports in the future.

\section{China's engagement with Rwanda}

China's engagement with Rwanda is predicated on the principles of non-interference and the One China Policy, and focuses on the mutual benefits both countries can gain through trade, investment and economic cooperation. China 
provides aid to Rwanda through Economic and Technical Cooperation (ETC), but there has been a shift towards providing official loans with government-subsidised interest rates and developing joint ventures between Chinese and Rwandan companies (Mohan and Power 2008). FDI projects can often resemble ETC because they are secured by official bilateral agreements, do not result in Chinese ownership of assets in Rwanda, and do not pose any significant financial risks to the Chinese companies involved (Kariuki et al. 2009).

China does not have a central aid agency and considers much information about its aid to be a state secret, so it is difficult to quantify.

Rwanda's Official Development Assistance Report does not include figures from China, India or Arab Funds because they are not captured in the Development Assistance Database. Still, these partners finance only 8 per cent of Rwanda's budget. Rwanda estimates that China's aid has totalled US $\$ 146$ million since 1971, being composed of about half in grants, one-third zero-interest loans, and one-fifth through preferential loans (Ministry of Finance and Economic Planning n.d.).

China's assistance is outlined in the external assistance budget put together by the Ministry of Finance and authorised by the National People's Congress. Ministries with jurisdiction over specific kinds of assistance oversee aid that falls in their domain (education, finance, health, science and technology and so forth) The Department of Foreign Aid in MOFCOM is responsible for aid policy and supervising implementation, as well as managing bids by Chinese companies for overseas projects (Kariuki et al. 2009). It is this body that administers grants and interest-free loans that are given to Rwanda, as well as the ExportImport Bank of China (China EximBank) under the Ministry of Finance and the Ministry of Foreign Affairs (MOFA).

To access Chinese aid, Rwanda must approach one of these authorities to negotiate the terms and conditions. Then, the two countries reach an economic and technical cooperation agreement (essentially a line of credit) against which the Rwandan government suggests projects. Chinese teams then carry out feasibility studies and plans and submit them to the relevant Rwandan ministry for approval. Each project must comply with the following criteria:

Assurance of technical feasibility and economic viability;

- Generation of social benefits;

- Selection of Chinese companies as the principal contractor or exporter;

- Procurement of no less than 50 per cent of equipment, materials, services, or technology from China;

- Advance procurement of local funds, equipment or labour needed for the project.

By mandating the use of Chinese firms and materials, these grants, interest-free or concessional loans to Rwanda are forms of tied assistance (Kariuki et al. 2009). In fact, 60-80 per cent of projects are assigned to Chinese companies selected by the EximBank and MOFCOM and then sanctioned by the Rwandan government (Alden and Alves 2009). China does this to help facilitate entry of Chinese products to Rwandan markets and also to help its companies gain the competitive edge they need to succeed in international trade.

The terms of Chinese loans are negotiated by joint permanent commissions that are established to represent the interests of both countries. This process includes the signature of an intergovernmental framework agreement, which defines the purpose, amount, maturity and interest rate of the loan as well as the signing of a loan agreement. Loans from China EximBank usually include a 35 per cent grant component. Interest rates vary from 1.25 per cent to 3 per cent, and the grace period is between five and eight years, with repayment over 10-20 years (Alden and Alves 2009). The capital is disbursed in successive portions, released against project benchmarks and paid directly to Chinese companies through the EximBank.

\section{The Department of Foreign Economic} Cooperation regulates Chinese companies operating overseas. Although in the past Chinese firms were closely in line with the state's agenda, they now have some relative autonomy, although ties between the Chinese Communist Party (CCP) and large Chinese multinationals are still strong.

However, smaller private Chinese firms that are independent of the Chinese agenda have also 
been encouraged (Mohan and Power 2008).

Furthermore, Chinese construction firms that traditionally relied upon state-financed projects have branched out and are now bidding competitively for publicly tendered infrastructure projects (Alden and Alves 2009). Provincial and local governments, which have been given greater authority to pursue economic policy abroad since the 1980 s, are also actively promoting their companies' interests and investments in Africa (ibid.).

\section{In 2007 China created the China-Africa}

Development Fund, which aims to encourage Chinese firms to invest in Africa in order to expand their market share, reach consumers and secure access to resources. It reduces the risk of investing in African countries for Chinese firms by providing financial support and advice. However, the fund requires African partners to put up a minimum of US $\$ 5$ million for joint ventures, which is difficult for most Rwandan entrepreneurs (Rwanda Focus 2008).

The Chinese Embassy in Rwanda also plays an important role in maintaining and enhancing the relationship between the two countries. It hosts cultural events and celebrations to mark important dates and foster goodwill between China and Rwanda. It also has an economic counsellor's office attached to it, which helps connect Rwandan and Chinese business people.

\section{Conclusions}

A significant aspect of China's approach to governance is the changing relations of state and business in China and its interplay in Africa. These relationships are quite disorganised at present, but there is growing pressure to develop them institutionally to make China's intervention in Africa more effective. The diversification of Chinese actors (and hence diverse interests) has made it very difficult for it to define its core interests in Africa.

As China's role has grown in Africa, so too have the number and range of government ministries and agencies, with over 20 of these now actively involved. This has given rise to constant administrative power struggles and interdepartmental dialogue and negotiation. Interviewees subtly hinted that this is reflected in relations between the Consular and Embassy sections in China's diplomatic missions in Africa.
However, the broad characteristic of Chinese engagement in Africa remains the same. It is based on the premise of equality among sovereign states and the idea of some kind of transnational governance standard contradicts the essentially reciprocal and horizontal nature of the relationship. No one stands in a position of authority over the other. If typical characteristics associated with governance, such as transparency, participation, openness and the rule of law, are to mean that China is expected to ensure that they are implemented, that would contradict the fundamental principles just outlined. Such concepts are regarded as highly ethnocentric in character being regarded as value-laden and culturally-based within Western societal norms. Instead, as several interviewees argued, 'Governance is basically a Western concept, we Chinese believe in Government, not governance.'

For example, under the terms of the DRC's 2008 agreement with China, a major part of its public affairs management is committed to the goals of the development projects and cannot be diverted for either short-term, populist, or even corrupt goals, through transient local political pressure. As for damage caused to the environment, that was to be understood and accepted in the context of China's contribution to infrastructure and to the need to accept some inevitable fallout of major natural resource development. The International Monetary Fund (IMF) and other UN specialised agencies are not impartial bodies in their criticism of an agreement like this between China and the DRC.

Claims for good governance in mining affect the contours taken in implementing the initial Sino-Congolese cooperation programme. The Congolese government renegotiated and reshaped the Chinese contract. However, as one interviewee said:

\section{Quarrels and pronouncements in favour of governance in an economy experiencing a manifest deficiency in viable players to boost the economy seem premature. In a global world, preaching good governance without investing significantly in improving the economy by dynamic and daring actors is not sustainable.}

The access to decent income seems a better way to enhance individual capabilities together with improving the living conditions of populations. 
The DRC currently receives some good returns from Chinese cooperation by strengthening its infrastructure, potentially benefiting the whole economy. However, the weak link in this deal is the limited technology and know-how transfer by the Chinese in favour of their own structures and its own population. Local civil engineering companies disappear, public agencies such as the Roads Office, the Office of Urban Roads and Canalization and the Office for Country Roads are bogged down and under-equipped. They are not firmly funded to take over to continue the maintenance of these infrastructures and China's 'key in hands' approach in infrastructure delivery certainly carries quick positive political dividends. But like a sleeping remedy, it delays or limits Congolese ownership. It appears to help, but does not help enough or necessarily always for the better. Respect for the diplomatic principle of non-intervention in Congolese affairs displayed by the Chinese side may not remain for long in relation to the balance of forces placing China at the forefront of economic intervention in the Congo. The apprehension is that a state cannot have so much potential and latent power and not use it, even in a discreet manner.

As the Rwandan experience indicates, the initiative is with the African country to decide when, where and how it wants development. China merely responds to requests and then endeavours to ensure that the participation it affords is effective. China itself is not responsible for whether the African side can mount sufficient civil or multilevel partners at sufficient levels to benefit fully from this exercise. Nor can China magically increase the African capacity to absorb technological transfer beyond the African capacity for its reception.

The Chinese literature and interviewees argue that, without elaborating a full theory, they are concerned with effective governance, with rebuilding real capacities, with pragmatic engagement with practical partners on the ground and with long-term partnerships, stretching over generations rather than just for the lifetime of a limited economic project. Here the governing idea is building capacities, a participative approach to rebuilding

infrastructure. This resonates with the argument that overcoming state fragility requires state resilience, without which good governance cannot be effective.
At the same time, the Chinese government's command of its own business society and that society's extension into Africa is not something over which it has clear direction. The Chinese officials and academics interviewed concur in the view that government-business relationships are currently fluid. There are opportunities for China's public and private sectors to build constructive relationships that contribute to both Chinese and African development goals.

However, during the fieldwork interviews, it was evident that business and NGO interviewees held a very different view from the Chinese government about how this might happen. Quite often they criticised the Chinese government and referred explicitly to the 'distant relationship between them and the government - the gap between the policy and the practice in Africa.' For example, in practice, the Chinese management of projects is not a straightforward, linear process of implementing a project plan but is a dynamic, non-deterministic process of improvisational actors continually shaping and reshaping practices, with unexpected and sometimes contradictory effects. This pattern of behaviour reflects both the lack of comprehensive direction of economic policy from Beijing, but also - especially with respect to the Western ideology of governance as participation by a wide range of transnational actors - that the constant Chinese search is for real talent on the ground which can be translated into effective action; effective in the sense of achieving the goals of the particular Chinese actor. This may well mean keeping a great deal of activity in Chinese hands.

In other words, it is not really practicable, given the fluidity of business-government relations among the Chinese, whether at home or in Africa - to be trying to address some ideologically-driven concepts of governance to Chinese political authorities. Not merely do they reject this in principle, because of their philosophy of diplomatic relations with African states, but the actual practice of economic activity by the Chinese in Africa, whether state-owned companies or private companies, is not being directed by any central authority according to any single plan. The processes of economic activity set in motion since the middle of the first decade of the century are too complex to have an overview, unless one wants to fall back on the very Western view of neoliberal laissez-faire, that so many hyper- 
dynamic individual actors are spontaneously propelled to be disciplined by a Western theory of governance, which must, in any case, be implemented by states since it is a public not a private belief system. In other words, the whole Western demand that China should as a state contribute to good governance in Africa is so riddled with contradiction, in terms also of Western ideology of the market, as to make no sense.

It is not surprising, therefore, to find that Chinese interviewees believe that progress in development in Africa is clearly dependent on

\section{Notes}

* This article is based on a project on China's role in Fragile States in Africa: Implication for Governance and Development. The authors would like to thank Ferdinand Mugumo Mushi and Rhiannon McCluskey for their background research assistance to the study. Any errors, however, are the authors'.

\section{References}

ACET (African Center for Economic Transformation) (2009) Looking East: ChinaAfrica Engagements: Rwanda Country Case Study, ACET, http://acetforafrica.org/wp-content/ uploads/2010/08/Looking-East-RwandaChina-case-study-2010.pdf (accessed 6 May 2014)

Alden, C. (2007) China in Africa, London: Zed Alden, C. and Alves, C. (2009) China and Africa's Natural Resources: The Challenges and Implications for Development and Governance, South African Institute of International Affairs (SAIIA), Governance of Africa's Resources Programme, Occasional Paper 41, Johannesburg: SAIIA

Carmody, P. and Taylor, I. (2010) 'Flexigemony and Force in China's Geoeconomic Strategy in Africa: Sudan and Zambia Compared', Geopolitics 15.3: 495-515

Chen, Z. and Li, H. (2011) 'The Underlying Causes and Implications of Political Unrest in Middle East and North Africa', Journal of Ideological \& Theoretical Education 150.06: 53-6

Corkin, L. (2011) 'Uneasy Allies: China's Evolving Relations with Angola', Journal of Contemporary African Studies 29.2: 169-80

d'Amour Mbonyinshuti, Jean (2013) 'Chinese Firm to Build Sheraton Kigali Hotel', The New Times, 25 January, www.newtimes.co.rw/news/ index.php? $\mathrm{a}=63195 \& \mathrm{i}=15248($ accessed 6 May 2014)
Africans themselves, not outside partners. This is one of the findings to emerge most clearly from the China interviews. Outsiders should continue to adhere to the principle of at least 'doing no harm', and could help if their motives and approaches were right. But they were not the main drivers of what would happen. Change had to come from within. The Chinese are frequently aware of deficits of political stabilisation, if not legitimacy on the African side. However, the Chinese themselves believe they are hardly in a position to contribute to resolving this from their own domestic experience.

1 Authors' interview.

2 Authors' interview.

3 Authors' interview.

4 Authors' interview.

5 Authors' interview.

Foster, V.; Butterfield, W.; Chuan, C. and Pushak, N. (2008) Building Bridges: China's Growing Role as Infrastructure Financier for SubSaharan Africa, Washington DC: World Bank

France Cooperation (2007) Position de la France sur les Etats Fragiles et les Situations de Fragilité (Paris: Stratégie Validée par le Co-secrétariat du CICID (Comité Interministériel de la Coopération Internationale et du Développement) le 27 septembre 2007 [Strategy Approved by the Co-secretariat of the CICID (Interministerial Committee on International Cooperation and Development) on 27 September 2007]

Hitimana, Bosco (2013) 'Rwanda Investment Rebounds', The Independent, 11 January, www.independent.co.ug/rwanda-ed/rwanda/ 7197-rwanda-investment-rebounds (accessed 15 May 2014)

Kagire, Edward (2012) 'China Comes to Rwanda's Rescue as Aid Cuts Begin to Hurt Economy', The East African, 29 December, www.theeastafrican.co.ke/news/China-comesto-Rwanda-rescue/-/2558/1653960/-/x 18sbrz//index.html (accessed 15 May 2014)

Kariuki, Julius G.; Byusa, Vincent and Ogunleye, Eric K. (2009) Looking East: ChinaAfrica Engagements. Rwanda Country Case Study, African Center for Economic Transformation Report, http://acetforafrica.org/wp-content/ uploads/ 2010/08/Looking-East-Rwanda- 
China-case-study-2010.pdf (accessed 15 May 2014)

Kjær, Anne Mette (2004) Governance, Cambridge: Polity

Li, X. and Xu, L. (2010) 'Research on Failed State in the Era of Globalization', Journal of Shandong University of Technology (Social Sciences) 26.1: 51-3

Magistad, M. (2011) 'Confucius in Kigali: China's Cultural Outreach in Rwanda', Public Radio International, 17 October, www.pri.org/ stories/2011-10-17/confucius-kigali-chinascultural-outreach-rwanda (accessed 15 May 2014)

Malunda, Dickson and Musana, Serge (2012)

'Rwanda Case Study on Economic

Transformation, Report for the African Centre for Economic Transformation (ACET)', Institute of Policy Analysis and Research - Rwanda (IPAR), www.ipar-rwanda.org/index.php?option = com_docman\&task $=$ doc_download $\&$ gid $=143$ $\&$ Itemid $=47$

MINAFFET (Ministry of Foreign Affairs and Cooperation, Rwanda) (2013) 'The 7th Session of Joint Committee on Economic, Technical and Trade Cooperation between Rwanda and China', Kigali, 13 May 2013, www.minaffet.gov.rw/index.php?id=886\&tx_ ttnews\%5Btt_news\%5D=531\&cHash= $911 \mathrm{foc} 366 \mathrm{dcb} 0 \mathrm{a} 9761 \mathrm{c} 85166 \mathrm{edbb6c8b}$ (accessed 15 May 2014)

MININFRA (Ministry of Infrastructure, Rwanda) (2013) 'Infrastructure Minister Visits Convention Center Under Construction in Kigali', MININFRA, www.mininfra.gov.rw/88/ ?no_cache $=1 \&$ tx_ttnews $\% 5 B$ tt_news $\% 5 D=95$ (accessed 15 May 2014)

Ministry of Finance and Economic Planning, Rwanda (n.d.) Official Development Assistance Report FY 2010/2011, www.devpartners.gov.rw/ fileadmin/templates/docs/Studies_and_ Reports/ODA\%20Reports/Final\% $200 \bar{D}$ A\% 20Report\%202010-2011.pdf (accessed 15 May 2014)

MOFCOM (Ministry of Commerce, China) (2006) 'China and Rwanda: 35 Years of Economic Cooperation', MOFCOM, http://rw2.mofcom.gov.cn/article/supply demandofchina/cooperation/200611/ 20061103619901.shtml (accessed 15 May 2014)
Mohan, G. and Power, M. (2008) 'New African Choices? The Politics of Chinese Engagement with African Development', Review of African Political Economy 35.115: 23-42

Namata, Berna (2011) 'China Targets Rwanda Infrastructure Projects', The East African, 3 September, www.theeastafrican.co.ke/news/ China-targets-Rwanda-infrastructureprojects/-/2558/1229816/-/lkcn4lz/-/index.html (accessed 15 May 2014)

National Institute of Statistics, Rwanda (2012) Statistical Yearbook 2012, http://statistics.gov.rw/ publications/statistical-yearbook-2012 (accessed 15 May 2014)

OECD (2007) Paris Declaration Evaluation Terms of Reference: Thematic Study on the Paris Declaration, Aid Effectiveness and Development Effectiveness, Paris: Organisation for Economic Co-operation and Development (OECD)

Power, M.; Mohan, G. and Tan-Mullins, M. (2012) Powering Development: China's Energy Diplomacy and Africa's Future, London: Palgrave Macmillan

Putzel, J. (2010) Why Development Actors Need a Better Definition of 'State Fragility', London: Crisis States Research Centre (GSRG), London School of Economics

Rwanda Focus (2008) Chinese Fund Offers Finance through Joint-ventures, 3 March, http://focus.rw/ wp/2008/03/chinese-fund-offers-financethrough-joint-ventures/ (accessed 15 May 2014) Ssuuna, Ignatius (2013) 'New Rwanda Airport Ready for Take-off', The East African, 13 April, www.theeastafrican.co.ke/business/NewRwanda-airport-ready-for-take-off/-/2560/ 1747438/-/oqexn5z/-/index.html 95 (accessed 15 May 2014)

Touchot, A. (2012) 'Rwanda, China, Rosy Business Romance', The Independent, 15 August, www.independent.co.ug/rwandaed/rwanda/6274-rwanda-china-rosy-businessromance- (accessed 15 May 2014)

World Bank (2009) Economy-Wide Impact of Oil Discovery in Ghana, World Bank, 30 November, http://siteresources.worldbank.org/ INTGHANA/Resources/Economy-Wide Impact_of_Oil_Discovery_in_Ghana.pdf (accessed 15 May 2014)

Zhou, Yugen (2011) Innovation of Government's Ruling Methods during Transitional Era, Guangzhou: Jinan University Press 